\title{
Exploring Museum Marketing Performance: A Case Study from Italy
}

\author{
Carlo Amenta \\ Dipartimento di Studi Giuridici, Economici \\ Biomedici, Psicosociopedagocici delle Scienze Motorie e Sportive, University of Palermo \\ Via Maggiore Toselli 87/B, 90143 Palermo, Italy \\ Tel: 3909-1620-5204Ｅ-mail: carlo.amenta@unipa.it
}

\begin{abstract}
The public funding of museums should be linked to performance results in order to reward institutions that are more efficient. Performance measurement tools rely heavily on figures based on visitors numbers and tickets sold. In this paper an indicator is proposed, called PMMP (Performance of Museum as a Marketing Product) consisting of 4 dimensions derived from the four P's of marketing. The tool is applied to two art and archaeology museums, one private and one public used as case studies in this exploratory phase. Publicly managed facilities could be proving inefficient in performing high levels of marketing performance, thus reducing visitors numbers. The subsequent revenues decrease makes it difficult to preserve the facility without asking for more public money. The simultaneous reduction in public funding asks for some criteria of selection and the indicator could be also useful as a checklist in evaluating museums' marketing strategies and for internal benchmarking assessment.
\end{abstract}

Keywords: Museums, Marketing, Indicator, Public sector, Service management

\section{Introduction}

Museums need an improvement in managerial skills. The process of change that started in the mid-80's (Kawashima, 1998), is still going on and is not easily accepted (Tobelem, 1997). One example concerns performance measurement that still relies on figures relating to the number of visitors and tickets sold (Zan, $2000^{\mathrm{b}}$; Office of the Deputy Prime Minister, 2005), even if the need for a broader perspective is not unrecognised (MLA, 2005). Rentschler et al. (2002) indicate how the emphasis on demand from the cultural policy statement has stimulated the increase of different performance measures.

In a period of tight constraints on public spending in the cultural sector in the continental Europe, where the dependence on public funding is relevant, an efficient performance measurement system is much needed. Welfare policies consume the lion share of the public budget for retirement schemes and national health systems. It seems difficult for the gap in managerial efficiency to be closed by publicly managed institutions, wherein the organization efficiency level, in most European countries, is notably low.

As Stiglitz (1989) points out, a public entity differs from other economic organizations in two particular features: it is the only organization with universal participation and it has coercive power over its members. Anyone born in a certain territory is automatically a member of that state, and therefore subject to its law. These features define the economic role of the state, assigning a fiduciary duty which forces the privileging of equity over efficiency in economic decisions. This influences management, employee hiring and performance evaluation criteria that, by not rewarding merit, can create a lack of managerial competence in state-run enterprises. The result is a kind of failure-of-the-state in which the public entity cannot keep pace with the changing needs of the citizens. Finally, the public entity is potentially forced to dispose of the management and even of the property of the facility that was originally intended to fulfill those needs.

The necessity of fostering a managerial attitude causes many problems. Basically, two different approaches have emerged: New Public Management theory (Allison and Kaye 1997, Bryce $2000^{3}$ ) suggests the application of managerial tools and techniques to the public and not-for-profit sector. The Public Governance approach (Kickert, 1997), focuses on the features of the public subject and tries to adapt those same managerial tools and techniques to it.

This debate strengthens the opinion that the only course of action the public subject should follow, in the interest of efficiency, is the progressive and complete retreat from any economic activity in the way indicated by libertarian economic literature (for an insight on the legal problems and controversial moral question that government funding of the arts can create see Sunstein, 2000). This paper will propose the adoption of regulation tools that heavily rely on an incentives (rewards) system, so that efficiency can be regained. The regulation could be useful in aligning the private interests of the facility's with those of the general public. By using these tools the public owner could check that private subjects do not succeed with disproportionate rent appropriation behaviour. Marketing could 
prove very effective in promoting mission efficiency in public organizations. Kotler and Levy (1969) broaden the concept of marketing and succeed in promoting its application as a managerial philosophy that could be applied to any sector. In public and not-for-profit sectors (Kotler, Andreasen; 1996) marketing could become a common ground, reconciling two different styles: the bureaucratic and administrative approach, typical of publicly managed organizations and the managerial and meritocratic approach of the private sector. A focus on consumer satisfaction could promote participation for a common goal and help to reconcile these different cultures.

In the case of museums the need for this change is evident. McLean (1997) underlines the problems that arise when an expertise-driven organization tries to become customer-driven. Any clash between these different cultures could paralyze museum activity. Mottner and Ford (2008) analyze how this contrast can be transformed in internal competition in order to produce a positive effect on museum performance. The building and implementation of performance measurement tools, relying on marketing and consumer focussed activities, could prove successful in creating common ground thus resolving what Liao et al. (2000) call the "marketing vs mission dilemma". In this regard, a political role can be assigned to performance indicators. By involving the organization at every level of the implementation process (Kaplan and Norton, 1996) they could prove successful in developing a common identity. In this sense Epstein and Manzoni (1998: 193) stress the role of this discussion inside organizations. The museum experience should be managed as a service "mediated by a number of socio-cultural, cognitive, psychological orientators, and physical and environmental conditions, all of which need to be seen as interrelated if a quality experience is to be provided" (Goulding, 2000: 269).

In this paper an indicator called PMMP (Performance of Museum as a Marketing Product) is proposed, made up of 4 dimensions constituting the four P's of marketing: 'Product', 'Place', Promotion' and 'Price' (note 1). Each dimension is subdivided into categories and for each of these, several quantitative variables are calculated. An additive model is then applied fitting the need for different levels of analysis. The score obtained for each variable is standardized by choosing a benchmark. A global score could be used as a synthetic way of comparing museums but the analysis can go further and deeper. Different institutions can be compared along several marketing aspects by looking at the results according to category or variable. The scale is developed according to Churchill (1979) suggested procedure. The categories and the variables are chosen from the literature relating to museum marketing. The data are collected from two museums in order to understand if they are easily available. No factor analysis is conducted so some improvements are needed and the study is exploratory. The main reason for not conducting factor analysis relies in the exploratory nature of the research. In order to conduct a proper factor analysis the data for the indicator should be collected on a sample of an adequate size. In this phase the indicator is calculated only to check the methodology and to improve the tool. The PMMP indicator improves traditional performance evaluation systems in the field. At an organizational level, the benchmarking process and a discussion of single variables could help to reconcile the two above-described cultures. It is also a tool the public subject owner could adopt as a reward instrument and as a soft regulation instrument. Moreover, public funding could be linked to performance results in order to reward museums that are more efficient and thus attract more money. The tool allows the evaluation of museums of different sizes in terms of visitor figures, thus reducing the usual gap in public funding distribution between large superstar museums and smaller ones. As shown in Figure 1 the basic idea is that publicly funded museums need managerial skills to attract more visitors and to improve their image. This should increase revenues from sources alternative to public funding such as ticket revenues, sponsorships and donorships, allowing a museum to survive in the current period of public spending constraints. Moreover the marketing performance tool could be used by public owner to reward market-oriented museums that should win a larger share of funds.

\section{Figure 1 about here}

Marketing is chosen as general framework because it is considered the managerial skill that can best help museums to accomplish their mission. The latter is the one stated by ICOM (2001): "A museum is a non-profit making, permanent institution in the service of society and of its development, and open to the public, which acquires, conserves, researches, communicates and exhibits, for purposes of study, education and enjoyment, material evidence of people and their environment.". In particular the museum's operations are well represented by marketing and its four P's. Moreover marketing strategies could prove particularly useful helping museums with their purposes. In the following section the indicator and its dimensions are presented along with the methodology used to standardize the score with a benchmarking system. After this, results from two Italian art and archaeology museums (publicly and privately owned) are presented. The case study methodology is chosen in order to test a hypothesis in the exploratory phase of the study $\left(\mathrm{Yin}, 2003^{\mathrm{a}, \mathrm{b}}\right.$ ). In the last section some critical aspects and further development are discussed. 


\section{Methodology}

The PMMP (Performance of Museum as a Marketing Product) indicator is built within a marketing theory framework and could be used to analyse the current situation and to direct the board effort toward goals linked to the sector's best practices. The literature considered in the development of the scale is reported in the subsequent table.

\section{Table 1 about here}

The main dimensions that constitute the indicator are the four P's of marketing and for each of them there are sub-dimensions (categories). For each category, several variables are considered. The denominator of each variable is chosen in order to allow comparisons between museums of different size. In order to obtain a standardized score, a benchmark for each variable is chosen. The benchmark is divided into five intervals (from -1 to +1$)$ to obtain a modulation scale. After each variable is calculated the score obtained must be compared with the modulation scale to give a standardized score. For example, the benchmark related to a disabled-modified stair is 1 (one disabled modified stair for every set of stairs inside the museum). The benchmark is divided by 5 to obtain intervals of 0.2 each. If the variable marks 0.33 (one set of modified stairs every three sets of stairs) a score of -0.5 is assigned because the variable score falls within the second interval of the five obtained in the division of the benchmark.

The standardization process of each variable $x_{i j}\left(i=1, . .11 ; j=1, . ., N_{i}\right)$, where $i$ characterizes the categories and $j$ the single variable, is:

$$
\begin{aligned}
& \text { score }\left(x_{i j}\right)=\left[-1 \text { if } \min \left(x_{i j}\right) \leq x_{i j}<\min \left(x_{i j}\right)+\right.\text { bench/5 } \\
& -0,5 \text { if } \min \left(x_{i j}\right)+\text { bench/5 } \leq x_{i j}<\min \left(x_{i j}\right)+2 * \text { bench } / 5 \\
& 0 \text { if } \min \left(x_{i j}\right)+2 * \text { bench/5 } \leq x_{i j}<\min \left(x_{i j}\right)+3 * \text { bench/5 } \\
& 0,5 \text { if } \min \left(x_{i j}\right)+3 * \text { bench/ } 5 \leq x_{i j}<\min \left(x_{i j}\right)+4 * \text { bench/5 } \\
& 1 \text { if } \min \left(x_{i j}\right)+4 * \text { bench } / 5 \leq x_{i j}<\max \left(x_{i j}\right)
\end{aligned}
$$

with

$$
\begin{array}{lllllll}
j=\left(N_{1}, \ldots N_{11}\right) & N_{1}=6 & N_{2}=7 & N_{3}=4 & N_{4}=7 & N_{5}=11 & N_{6}=13 \\
N_{7}=5 & N_{8}=4 & N_{9}=2 & N_{10}=3 & N_{11}=1 &
\end{array}
$$

In this way the notation $x_{34}$ corresponds to the fourth variable in the third category: 'No. of staff members assigned to the room/total no. of staff members'. Choosing the benchmark is extremely problematic, and this could be an interesting area for further investigation to improve the indicator. As suggested in Epstein and Manzoni (1998), the benchmarks are chosen based on the museum marketing literature or previous research. Each benchmark has also been discussed with professionals from the participating museums. In the process of building an indicator, the stage during which the people involved must estabilish its general features is extremely important. In museums the benchmarking process could become the field wherein managers and curators try to find a compromise between their differing views on museum management.

The score range between -1 and 1 with a negative evaluation assigned to the minimum score in the range and 0 neutral. The sum of different scores is made per row in order to obtain an evaluation for each category. The same weight is assigned to each variable but a different choice could be made in order to stress the importance of different strategic marketing policies.

A score for each dimension could be obtained by adding up the score of either each variable or category thus allowing a comparison between different aspects at different depths.

The first dimension is 'Product' and there are four related categories:

Accessibility; this category considers whether visitors can easily find and access the museum. Its variables account for parking, means of transport to the museum and facilities that could allow differently-abled people to fully enjoy the experience. 
Services; all complementary services to the visit are considered. Examples may include restaurants, reading rooms, laboratories or educational activities managed by the staff.

Staff; a well trained and motivated staff is an important strength for museum activity. While controlling rooms for safety reasons, they could be also considered as information-giving agents with regard to the visit or the pieces displayed.

Availability; this regards all the elements that contribute to raising the satisfaction level of the visitor. A museum which scores high in this category is managed by a board that knows how to transform a visit into an experience. Variables in this category are related to room overcrowding, the availibility of information or seats near the art pieces.

\section{Table 2.1 about here}

The variable concerning museum shop prices and their division into different levels is included in the consideration of the visit's educational and emotional role. Nowadays visitors like to take away a souvenir from the museum which will remind them of the experience. From a marketing perspective, this attention to memory, and the whole concept of reminding people of their visit, could play a central role (Mottner and Ford, 2005). For this reason, in deciding the score, the presence of low cost articles inside the museum shop and the frequency with which these are bought, are considered as a positive factor. These kinds of articles (pens, bookmarks, posters) could be used or seen every day by visitors. They might remember their pleasant experience and decide to come for another visit. The variable "No. of agreements with schools or other educational institutions/total no. of educational institutions in the city' - considers the important role of museums in involving children (considered 'visitors of tomorrow' in museum literature). Addis (2005) highlights the importance of the use of new technologies for educational purpose. Exposure to art and historical displays during childhood or adolescence could encourage people to appreciate both art and museums as they develop into adulthood. It is not clear if this kind of long term effect actually happens but the policy of attracting children could prove efficient in positively influencing the current demand for museums (families with children, schools and colleges). The variable 'No. of children or young visitors / annual no. of visitors' considers the presence of children as problematic to other visitors' experience. The yelling and laughing of groups of children inside a museum could prove upsetting for a visitor who may want to enjoy the quiet and the calm of a room full of paintings. It may, however, be different in the case of a visit to a science museum where interactivity is considered important for educational purposes. In the 'Staff' category a variable accounts for the role played by volunteers inside a museum's organization even if in Italian museums it is not an organizational aspect which is fully exploited. Included in the category 'availability' are variables that measure how the museum management tries to minimize 'museum fatigue' focussing on overcrowding problems, boredom and the visitors' uneasiness with the visit orientation or information needs. Overcrowding is considered in two variables: 'Average no. of daily visitors/exhibition space' and 'No. of art pieces/ exhibition space'. Defining overcrowding is quite a difficult task. It is important to underline the difficulties that are linked to the concept specifications and to its measurement process. In fixing the benchmark, the opinions of the museum experts collected from personal interviews are considered.

The second dimension is Place. It refers to strategies and policies that a museum may exploit in order to 'bring' the product to the visitors. In what ways does a museum reach the visitors? How does it distribute its collection? The categories considered are 'place experience' and 'external'. Even if the existence of this marketing element for museums is not universally accepted (McLean, 1997) the classical classification of marketing mix is followed to individuate a universal framework. Kotler and Kotler (1998) describe some variables that are included in the second category. The variables in the first category could also be included in the dimension 'Product'. They are placed in a category inside 'Place' because all the variables considered account for the use of tools which can enhance a museum experience, but are optional for the visitor. In this sense they could not be considered naturally bound to the museum product.

\section{Table 2.2 about here}

Place experience; the tools that a museum puts at the disposal of the visitors to facilitate the enjoyment of the museum collections are analysed in this category. Audio guides, multimedia tools, displays and exhibition paths are all effective methods which allow the visitor to fully enjoy the experience. In this sense, all these processes transport the piece from the wall where it is shown to the heart and mind of the visitor, explaining it and providing information, enriching it with new and unexpected features.

External; in this category the indicator contains variables regarding tools and methods which bring a museum's product to the visitor and are not related to advertising, which is properly placed in 'Promotion' dimension. 
In the first category the variable 'Special tours / total guided visits' accounts for the special tours that are created for children or that include some specific features like historical costumes or settings. In the category 'external', the museum web site is not considered but an evaluation should be included. The heterogeneity and variety of museum websites is difficult to comprehend only according to some variables. A proper measurement scale has been developed and its score could be considered by the PMMP indicator, under the category 'external' in the 'Place' dimension. It is constituted of ten categories with three items per category. Every item is a dummy variable that concerns a certain characteristic of the website. It counts a 0 if the characteristic is not present and 1 if it is. Neither of the museums where the indicator was applied has not a web site at the time of data collection. For that reason the web site indicator is not reported in this paper. It is extensively explained in Martelli (2002:97-116) together with the relevant literature. The variable concerning donations aims at measuring the relationship with the community. The variable on artworks reflecting local culture is important in understanding if the museum will be able to attract foreign tourists.

The indicator contains two categories for 'Promotion', the dimension that considers the communication strategy:

Advertising; concerns all the traditional tools of marketing promotion: advertising campaigns, leaflets and events management. With regard to marketing situation of European museums (see Wober et al., 2000) the score that many organizations may obtain in this category could be very low, considering that these tools are used efficiently in every marketing oriented firm.

Image; considered in this category are the tools and policies that aim both at creating a reputation and fostering a positive attitude in the minds of the audience. One example is the variable concerning sponsorship. The ability to obtain a large number of sponsors is an adequate proxy for a good reputation built through public relations. The presence of a brand is another important performance variable, according to the strategic relevance of brand equity.

For 'Promotion' the advertising campaign is defined as a set of advertising messages diffused in an established interval of time, on at least two of the three major medium (TV, newspaper and radio). The variable 'Events not linked to cultural exhibition / none of city inhabitants' measures the ability of the board to promote museum activities. The museum brand is evaluated only with regards to its presence and the considerations of the heterogeneity and complexity of websites also apply here. A proper evaluation tool should be considered but it is not, in this paper. The role of focus groups in measuring brand equity should also be considered. Public relations strategies, an important component of promotional activities, where not considered due to the limited importance of these activities in Italian museums. It deserves however more consideration and some items should be added.

\section{Table 2.3 about here}

The fourth dimension is 'Price' and is composed of three categories. Pricing policies are analyzed by looking at the financial autonomy of the organization. Considering this, especially in Europe, many cultural institutions are publicly financed and pricing strategies are controlled by the public owner. Different using for museum spaces is also considered.

The categories are:

Pricing policies: capability and autonomy in fixing prices are considered.

Incentive policies: the creation and development of museums' members associations are considered as a clue as to how a museum is trying to widen its audience by segmenting its market.

Differentiation: the strategies considered in order to obtain revenues aside from tickets sales.

In the category on price policies the first variable takes in to account the widespread public ownership of European (and Italian in particular) museum. For that reason the decision process on price fixing is not completely in the hands of the museum's board, and this could be considered a relevant constraint to museum marketing activities.

\section{Table 2.4 about here}

\section{Results}

The PMMP indicator was applied to two Italian museums of art and archaeology in Palermo, Sicily, in 2003.

The application was useful in order to understand the feasibility of data and to discuss the indicator with museum experts. In the case study the hypothesis to be checked was that the 'Fondazione Banco di Sicilia - Museo Mormino', a private museum managed by a bank-created trust, should score higher than 'Museo Archeologico Salinas', owned by the Regional Council. As Frey and Meier (2002) show, the reason is that public museums are relying exclusively on public grants and their board have a loss refund guarantee. Directors of private museums have a strong incentive to fully exploit marketing competences in order to increase their income. Both museums 
focus mainly on archaeological exposition even if "Fondazione Banco di Sicilia - Museo Mormino" also has some important classical and contemporary art collections. The data was collected using a questionnaire for the museum curator or director.

\section{Table 3 about here}

In the table, results for the PMMP indicator are shown at the dimension level and confirm the hypothesis. Only in the 'Place' dimension the publicly owned museum scores on a par with the private. The reason is that all the variables in that dimension rely heavily on the employment of human resources. Due to budget constraints the private museum employs a limited number of workers, whereas the public one has an excess of human resources, as often happens in publicly owned companies, mainly for political patronage reasons. This result from the exploratory phase of the study suggests that some correction or a proper weighting process for the PMMP indicator is needed to introduce budget efficiency consideration.

The overall score for both museums is negative. This result confirms the general opinion on marketing activities formed on a visit to either of the two participant museums. There is a general lack of care for visitor needs and often this casts a shadow over the splendor of the exhibits. Due to space constraints and to avoid overwhelming data description the results for each variable as well as those regarding the categories are omitted. Some results are also confirmed by the opinion of the professionals from the participant museums. For the private museum the Director recognized the lack of care for tourists that emerged from the results. At the public museum the lack of autonomy from the public owner and some problems with staff managing were also confirmed.

\section{Conclusion}

The PMMP indicator could be useful in recognizing and rewarding museums with a good marketing performance. It could be applied to publicly owned museums that are facing problems with funding, in the current state budget situation of many European countries. The public subject requires proper evaluation tools in order to improve managerial efficiency and to reduce the sector dependency on public funding. Museum performance indicators are usually based on attendance figures and this may well penalize smaller museums. In this sense, an indicator based on marketing performance could give a chance to every museum to prove their board's managerial skill and to gain proper reward. Moreover, marketing strategies aim at increasing visitor figures and satisfaction in a way that usually increases revenues. These revenues partially substitute public funding, thus paving the way to financial improvement: rewarding museums for marketing activities means reducing their dependence on public funding. A proper funding scheme could use the PMMP indicator in order to distribute at least half of the annual budget according to a ranking based on an indicator score for each museum. The other half could be equally shared in order to assure the survival of every cultural institution. The depicted model could be applied in every state-subsidised sector like sport or not for profit organization in order to improve efficiency in the assignment of public funding. This could also improve relationships between levels in government support and marketing activities, as described in Kirchner et al. (2006) for symphony orchestras.

Considering the paper only presented a case study, further research should first aim at validating the PMMP indicator following the Churchill (1979) procedure, collecting data on a proper sample and conducting factor analysis. Then, once the proposed indicator can be considered valid and reliable the relationship between the PMMP indicator and visitor satisfaction measured by a questionnaire can be further investigated. The hypothesis is that museums scoring highly on the performance indicator also show a high degree of visitor satisfaction according to the equation:

$$
C S_{i}=\beta_{0}+\beta_{1} M P_{i}+\varepsilon_{i}
$$

where:

$C S_{i}=$ customer satisfaction level for each museum in the sample;

$M P_{i}=$ Marketing performance score measured applying the PMMP indicator for each museum in the sample;

The coefficient $B_{l}$ should be positive in order to respect the hypothesized causal effect.

A confirmation of this hypothesis could give the proper robustness to the described evaluating tool. The dependant variable in the model could also be a quantitative one such as the number of visitors or annual revenues. The evaluating tool presented in this paper should be also ameliorated with reference to a benchmarking process. Its application on a proper sample of museums in a specific country or on the 'best in class' in each museum category could result in varying benchmarks. 
Currently, the indicator could be useful as a check list for evaluating museums' marketing strategies and for internal benchmarking assessment. In these cases, the weighting of the variables could also be reconsidered in order to give importance to various aspects of museum management. Weighting discussion could prove particularly effective in order to improve the reconciliation process between managers and curators, because every element of the organization should be involved in the process and obtaining a final result is mandatory.

\section{References}

Addis M. (2005). New technologies and cultural consumption - edutainment is born! European Journal of Marketing, Vol. 39, No. 7/8, 729-736.

Allison M., \& Kaye J. (1997). Strategic Planning for Nonprofit Organizations. Wiley, New York, NY

Ashworth J., \& Johnson P. (1996). Sources of 'value for money’ for museum visitor: some survey evidence. Journal of Cultural Economics, Vol. 20: 67-83.

Bagdadli S. (1997). Il museo come azienda - Management ed organizzazione al servizio della culura, ETAS, Milano.

Booth B. (1998). Understanding the information needs of visitors to museums. Museum Management and Curatorship, Vol. 17, no. 2: 139-157.

Bryce H.J. $\left(2000^{3}\right)$. Financial and Strategic Management for Nonprofit Organizations, Jossey Bass, San Francisco, Cal.

Camuffo D., Van Grieken R., Busse H. J., Sturaro G., Valentino A., Bernardi A., Blades N., Shooter D., Gysels K., Deutsch F., Wieser M., Kim O., \& Ulrych U. (2001). Environmental monitoring in four European museum. Atmospheric Environment, no. 35: 15-28.

Churchill G.A. (1979). A paradigm for developing better measures of marketing constructs. Journal of Marketing Research, 16: 64-89.

Economou M. (1998). The evaluation of museum multimedia applications: lessons from research. Museum Management and Curatorship, Vol. 17 no. 2: 173-187.

Epstein M., \& Manzoni J.F. (1998). Implementing Corporate Strategy: From Tableaux de Bord to balanced Scorecards. European Management Journal, Vol. 16, no. 2: 190-203.

Frey B.S. (1998). Superstar museums: an economic analysis. Journal of Cultural Economics, Vol. 22: 113-125.

Frey B.S., \& Meier S. (2002). Museum Between Private and Public: The Case of Beyeler Museum in Basle. Working Paper n. 116, Institute for Empirical Research in Economics, University of Zurich, Zurich

Funari S., \& Viscolani B. (1998). Allocazione dinamica delle risorse in un museo: il problema della gestione della congestione. Economia della Cultura, no. 2: 169-183.

Garrod B., \& Fyall A. (2000). Managing Heritage Tourism. Annals of Tourism Research, Vol. 27, no. 3: $682-708$. Garrod B., Fyall A., \& Leask A. (2002). Scottish visitor attractions: managing visitor impacts. Tourism Management, 23: 265-274.

Goulding, C. (2000). The museum environment and the visitor experience. European Journal of Marketing, Vol. 34 No. 3/4, 261-78.

Goulding, C. (2001). Romancing the past. Heritage visiting and the nostalgic consumer. Psychology and Marketing, Vol. 18 (6): 565-592.

Gray C.M. (1998). Hope for the future? Early exposure to the arts and adult visits to art museums. Journal of Cultural Economics, Vol. 22: 87-98.

Harrison J. (1997). Museum and touristic expectations. Annals of Tourism Research, Vol. 24, no. 1: 23-40.

ICOM website. (2008). [Online] Available: http://icom.museum/statutes.html\#2 (September 2008)

Johnson P., \& Thomas B. (1998). The Economics of museums: a research perspective. Journal of Cultural Economics, Vol. 22: 75-85.

Kaplan R.S., \& Norton D.P. (1996). The balanced scorecard: translating Strategy into Action, HBS Press, Boston, Mass.

Kawashima N. (1998). Knowing the Public. A Review of Museum marketing Literature and Research. Museum Management and Curatorship, Vol. 17, no. 1: 21-39. 
Kickert W.J.M. (1997). Public governance in the Netherlands: an alternative to Anglo-American 'managerialism. Public Administration, no. 4: 731-752.

Kirchberg V. (1998). Entrance fees as a subjective barrier to visiting museums. Journal of Cultural Economics, 22: $1-13$.

Kirchner T.A., Markowsky E.P., \& Ford J.B. (2006). Relationships among levels of government support, marketing activities, and financial health of nonprofit performing arts organizations. International Journal of Nonprofit and Voluntary Sector Marketing, Vol.12, Issue 2, 95-116.

Kotler N., \& Kotler P. (1998). Museum strategy and marketing, Jossey Bass, San Francisco, Cal.

Kotler P., \& Andreasen A.R. (1996). Strategic Marketing for NonProfit Organization, Prentice Hall, Upper Saddle River, N. J.

Kotler P., \& Levy S. J. (1969). Broadening the Concept of Marketing. Journal of Marketing, Vol. 33 no. 1: 10-15.

Liao M-N, Foreman S., \& Sargeant A. (2001). Market versus social orientation in the nonprofit context. International Journal of Nonprofit and Voluntary Sector Marketing, 6(3): 254-269

Light D. (1996). Characteristics of the audience for events of heritage site. Tourism Management, Vol. 17, no. 3: 183-190.

Martelli S. (2002). Comunicazione multidimensionale - I siti internet di istituzioni pubbliche ed imprese., Franco Angeli, Milano.

McLean F. (1997). Marketing the museum. Routledge, London, UK.

MLA-Museum, Libraries and Archives Council. (2005). Developing Performance Indicators for Local Authority Museums, Libraries and Archives.

Mottner, S., \& Ford J.B. (2005). Measuring nonprofit marketing strategy performance: the case of museum stores. Journal of Business Research, 58: 829-840.

Mottner, S., \& Ford J.B. (2008). Internal competition in a nonprofit museum context: development of a scale. International Journal of Nonprofit and Voluntary Services Marketing, 13: 177-190.

Office of the Deputy Prime Minister. (2005). Best Value Performance Indicators: 2005/06.

Rentschler R., Radbourne J., Carr R., \& Rickard J. (2002). Relationship marketing, audience retention and performing arts organisation viability. International Journal of Nonprofit and Voluntary Services Marketing, Vol. 7 no. 2: $118-130$.

Schouten F. (1995). Improving visitor care in heritage attractions. Tourism Management, Vol. 16, no. 4: $259-261$.

Stiglitz J. E. (1989). The Economic Role of The State, Blackwell, Oxford.

Sunstein C.R. (2000). Culture and Government Money: a Guide for the Perplexed. working paper, University of Chicago, Chicago, 27 April.

Tobelem J.M. (1997). The Marketing Approach in Museums. Museum Management and Curatorship, Vol. 16, no. 4: 337-354.

Verdassdonk H., van Rees C.J., Stokmans M, van Eijck K. (1996). The impact of experiental variables on patterns of museum attendance: the case of the Noord-Brabant Museum. Poetics, vol. 24: 181-202.

Walter T. (1996). From museum to morgue. Electronic guides in roman Bath. Tourism Management, Vol. 17 no. 4 : 241-245.

Wober K., Grabler K., \& Jeng J.M. (2000). Marketing professionalism of cultural institutions in Europe. Journal of Euromarketing, Vol. 9 (4): 33-55.

Yin R.K. (2003a). Case study research. Design and Methods - $3^{\text {rd }}$ edition, Applied Social Research Methods Series, Vol. 5, SAGE Publications, Thousand Oaks, Cal.

Yin R.K. (2003b). Applications of Case study research $-2^{\text {nd }}$ edition. Design and Methods, Applied Social Research Methods Series, Vol. 5, SAGE Publications, Thousand Oaks, Cal.

Zan L. $\left(2000^{\mathrm{a}}\right)$. Managerialisation processes and performance in arts organisations: the Archaelogical Museum of Bologna. Scandinavian Journal of Management, 16: 431-454.

Zan L. $\left(2000^{\mathrm{b}}\right)$. Management and the British Museum. Museum Management and Curatorship, Vol. 18, no. 3: 221-270. 


\section{Note}

Note 1 . In service marketing literature 7 P's are very often presented instead of the 4 classical P's. Since the three more P's can be considered as a specification of the Product dimension I preferred not to add any more dimension. This decision also contributes to the specification of a parsimonious model.

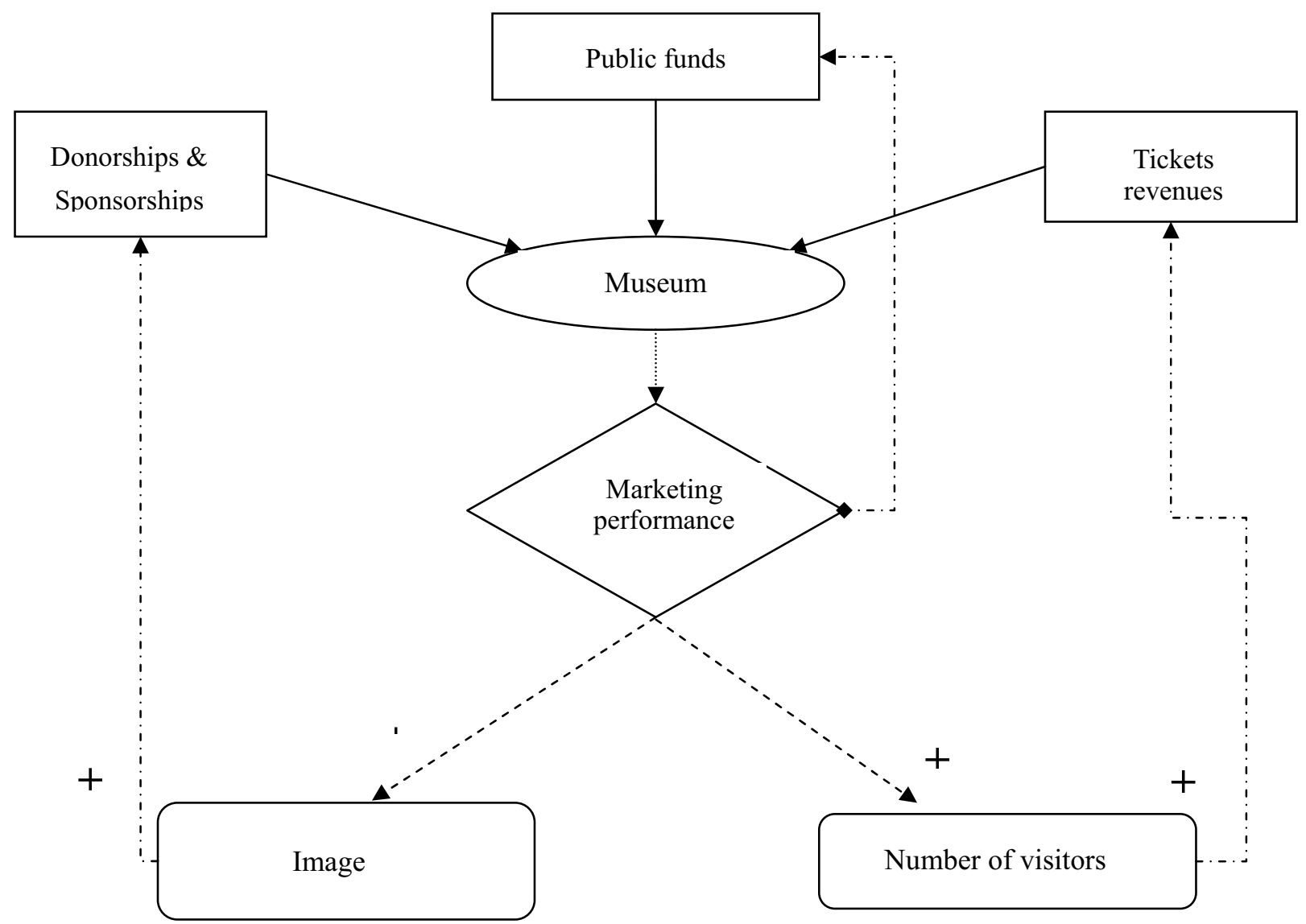

Table 1. References for the development of the PMMP indicator, divided by categories

\begin{tabular}{|c|c|}
\hline Category & References \\
\hline Accessibility & $\begin{array}{l}\text { Ashworth J., Johnson P. (1996); Frey B.S. (1998); Garrod B., Fyall A., (2000); Kotler N., Kotler P. } \\
\text { (1998); Schouten F. (1995); }\end{array}$ \\
\hline Museum services & $\begin{array}{l}\text { Ashworth J., Johnson P. (1996); Frey B.S. (1998); Goulding C. (2000); Gray C. M. (1998); Johnson } \\
\text { P., Thomas B. (1998); Kotler N., Kotler P. (1998); McLean F. (1997); Schouten F. (1995); Tobelem } \\
\text { J.M. (1997); Zan L. }\left(2000^{\mathrm{a}}\right) \text {; Zan L. }\left(2000^{\mathrm{b}}\right) \text {; }\end{array}$ \\
\hline Staff & Bagdadli S. (1997); Johnson P., Thomas B. (1998); Kotler N., Kotler P. (1998); McLean F. (1997); \\
\hline Availability & $\begin{array}{l}\text { Ashworth J., Johnson P. (1996); Camuffo D. et al (2001); Funari S., Viscolani B. (1998); Garrod B., } \\
\text { Fyall A., (2000); Goulding C. (2000); }\end{array}$ \\
\hline Place experience & $\begin{array}{l}\text { Booth B. (1998); Economou M. (1998); Goulding C. (2001); Kotler N., Kotler P. (1998); Light D. } \\
\text { (1996); Verdassdonk H. et al. (1996); Walter T. (1996); }\end{array}$ \\
\hline External & Harrison J. (1997); Kotler N., Kotler P. (1998); McLean F. (1997); Zan L. (2000ª); \\
\hline Advertising & $\begin{array}{l}\text { Frey B.S. (1998); Light D. (1996); Kotler N., Kotler P. (1998); McLean (1997); Tobelem J.M. (1997); } \\
\text { Zan L. (2000a); }\end{array}$ \\
\hline Image & Bagdadli S. (1997); Kotler N., Kotler P. (1998); McLean (1997); \\
\hline Pricing policies & $\begin{array}{l}\text { Bagdadli S. (1997); Garrod B. et al. (2002); Kirchberg V. (1998); Kotler N., Kotler P. (1998); McLean } \\
\text { F. (1997); }\end{array}$ \\
\hline Incentive Policies & Kotler N., Kotler P. (1998); \\
\hline Differentiation & Kotler N., Kotler P. (1998); \\
\hline
\end{tabular}


Table 2.1. Variables for Product dimension for the PMMP indicator, divided by categories and with the related benchmarks

\begin{tabular}{|c|c|c|}
\hline Category & Variables & Benchmark \\
\hline \multirow[t]{6}{*}{ Accessibility } & Disabled modified stairs / total no. of stairs & 1 \\
\hline & Disabled modified toilets / total no. of toilets & 1 \\
\hline & No. of cars parking boxes / daily average no. of visitors & 0,5 \\
\hline & No. of bus stops within $500 \mathrm{mt}$ & 1 \\
\hline & No. of metro stops within $500 \mathrm{mt}$. & 1 \\
\hline & No. of taxi ranks within $500 \mathrm{mt}$. & 1 \\
\hline \multirow[t]{7}{*}{ Museum services } & Product analysis for the museum shop based on different prices & $\begin{array}{c}1 \text { if } 50 \% \text { of } \\
\text { merchandise costs } \\
\text { less than } 50 €\end{array}$ \\
\hline & No. of restaurant inside the museum / daily average no. of visitors & $1: 50$ \\
\hline & No. of restaurant within $500 \mathrm{mt}$. of the museum / daily average no. of visitors & $2: 50$ \\
\hline & Workshops or courses opened to public / annual no. of visitors & $4: 100$ \\
\hline & $\begin{array}{c}\text { No. of staff working hours dedicated to educational activities (even outside the } \\
\text { museum )/total annual no. of working hours }\end{array}$ & 0,1 \\
\hline & $\begin{array}{l}\text { No. of agreements with schools or other educational institutions / total no. of } \\
\text { educational institutions in the city }\end{array}$ & 0,1 \\
\hline & No. of library seats / daily average no. of visitors & 0,1 \\
\hline \multirow[t]{4}{*}{ Staff } & No. of professional training hours for the staff/annual no. of working hours & 0,2 \\
\hline & No. of staff members / daily average no. of visitors & $1: 50$ \\
\hline & No. of volunteers / total no. of staff members & 0,5 \\
\hline & No. of staff members assigned to the room / total no. of staff members & 0,5 \\
\hline \multirow[t]{7}{*}{ Availability } & Average no. of daily visitors/exhibition space (mt.) & $1: 5$ \\
\hline & No. of art pieces/ exhibition space (mt.) & $1: 5$ \\
\hline & No. of children or young visitors / annual no. of visitors & $\begin{array}{c}\text { Depends on } \\
\text { museum exhibition }\end{array}$ \\
\hline & No. of seats / daily average no. of visitors & 0,5 \\
\hline & No. of seats / total metres of visiting path in the museum & $1: 5$ \\
\hline & No. of information points / total no. of rooms & $1: 1$ \\
\hline & No. of information points / daily average no. of visitors & 0,2 \\
\hline
\end{tabular}


Table 2.2. Variables for Place dimension for the PMMP indicator, divided by categories and with the related benchmarks

\begin{tabular}{|c|c|c|}
\hline & Variables & Benchmark \\
\hline \multirow[t]{11}{*}{ Place experience } & No. of directional signs / total metres of visiting path in the museum & $1: 10$ \\
\hline & No. of explanatory posters / total no. of art pieces & $1: 1$ \\
\hline & Total no. of guided tours per year / daily average no. of visitors & $1: 20$ \\
\hline & No. of themed exhibitions / total annual exhibitions & 0,5 \\
\hline & No. of audio guides rented / annual no. of visitors & 0,5 \\
\hline & No. of audio guides rented / total no. of guided tours & 0,1 \\
\hline & No. of multimedia tools / daily average no. of visitors & 0,5 \\
\hline & No. of multimedia tools / exhibits displayed & $1: 1$ \\
\hline & Annual no. of guided visits / total hours available for visits & $2: 1$ \\
\hline & Annual no. visits for children / total annual no. of child visitors & $1: 15$ \\
\hline & Special tours / total guided visits & 0,5 \\
\hline \multirow{13}{*}{ External } & No. of art pieces from local culture / total no. of art pieces & 0,6 \\
\hline & No. of active agreement with local political institutions / total political institutions & $1: 1$ \\
\hline & No. of donations and legacies from local community / total inhabitants & $1: 10000$ \\
\hline & Weekly opening times / total time available per week & 0,5 \\
\hline & Days open / total annual working days & $1: 1$ \\
\hline & Holiday days open / total holiday days per year & $1: 1$ \\
\hline & No. of activities organized for tourists / no. of non resident average daily visitors & $1: 100$ \\
\hline & Agreements with tour operators / average no. daily tourists & $1: 500$ \\
\hline & No. of time the museum is cited in council cultural tours / total council cultural tours & $1: 1$ \\
\hline & No. of art pieces loans from other institutions / total no. of art pieces & 0,05 \\
\hline & No. of days for museum travelling exhibitions / total no. of available days per year & 0,5 \\
\hline & No. of cities visited with travelling exhibition / no. of annual museum visitors & $1: 10000$ \\
\hline & Museum Journal volumes per year & 6 \\
\hline
\end{tabular}


Table 2.3. Variables for Promotion dimension for the PMMP indicator, divided by categories and with the related benchmarks

\begin{tabular}{|c|l|c|}
\hline Category & \multicolumn{1}{|c|}{ Variables } & Benchmark \\
\hline \multirow{4}{*}{ Advertising } & advertising campaigns & 2 per year \\
\cline { 2 - 3 } & No. of leaflets distributed by museum / total no. of copies printed & $1: 1$ \\
\cline { 2 - 3 } & No. of advertising placards / promotion annual budget & 0,1 \\
\cline { 2 - 3 } & No. of "blockbuster" events organized in the year & 1 per year \\
\cline { 2 - 3 } & Events not linked to cultural exhibition/ no. of city inhabitants & $1: 50000$ \\
\hline \multirow{5}{*}{ Image } & Museum brand & Yes \\
\cline { 2 - 3 } & Received sponsorships / annual no. of visitors & 0,05 \\
\cline { 2 - 3 } & No. of mailing list records / annual no. of visitors & 0,02 \\
\cline { 2 - 3 } & Room rented to other institutions or companies/ total rooms available & 0,5 \\
\hline
\end{tabular}

Table 2.4. Variables for Price dimension for the PMMP indicator divided by categories and with the related benchmarks

\begin{tabular}{|c|c|c|}
\hline Category & Variables & Benchmark \\
\hline \multirow[t]{2}{*}{ Pricing policies } & $\begin{array}{l}\text { The price is fixed by the board; the price is decided together with the public owner; the } \\
\text { price is imposed by the public owner }\end{array}$ & $\begin{array}{l}\text { Max; Half; } \\
\text { Min; }\end{array}$ \\
\hline & Presence of discount tickets linked to other attractions and cumulative tickets & Yes \\
\hline \multirow{3}{*}{$\begin{array}{l}\text { Incentive } \\
\text { Policies }\end{array}$} & Price incentive policies including entrance + transport & Yes \\
\hline & No. of different pricing categories / total no. of possible different categories & $1: 1$ \\
\hline & N. of incentive initiatives / total members of museum friends association & 1.20 \\
\hline Differentiation & Revenues from room locations / total revenues & 0,1 \\
\hline
\end{tabular}

Table 3. Results from the application on two museums, divided by categories

\begin{tabular}{|c|c|c|}
\hline Museum & Dimension & Global score \\
\hline \multirow{4}{*}{ Museo Archeologico Salinas } & Product & $-7,5$ \\
\cline { 2 - 3 } & Place & $-9,5$ \\
\cline { 2 - 3 } & Promotion & -5 \\
\cline { 2 - 3 } & Price & $-3,5$ \\
\hline \multirow{2}{*}{$\begin{array}{c}\text { Fondazione Banco di Sicilia } \\
\text { - Museo Formino }\end{array}$} & Product & -3 \\
\cline { 2 - 3 } & Place & $-9,5$ \\
\cline { 2 - 3 } & Promotion & $-0,5$ \\
\cline { 2 - 3 } & & -2 \\
\hline
\end{tabular}

